\title{
Commentary \\ Human Trafficking: Fighting the Illicit Economy with the Legitimate Economy
}

\author{
Louise Shelley ${ }^{1}$ and Christina Bain ${ }^{2, *}$ \\ ${ }^{1}$ School of Policy, Government and International Affairs, Terrorism, Transnational Crime and Corruption Center, \\ George Mason University, Arlington, Virginia 22201, USA; E-Mail: Ishelley@gmu.edu \\ ${ }^{2}$ Initiative on Human Trafficking and Modern Slavery, Office of the President, Babson College, Wellesley, MA 02457, \\ USA; E-Mail: cbain@babson.edu \\ * Corresponding author
}

Submitted: 17 December 2014 | Accepted: 30 December 2014 | Published: 23 February 2015

\begin{abstract}
Since the beginning of research on human trafficking, there has been attention paid to the challenges surrounding the illicit economy. In creating new strategies and initiatives on combatting human trafficking, there needs to be more discussion surrounding the legitimate economy and how the business sector can make an impact in the fight against trafficking. Currently, there is a growing movement of businesses that are looking to address human trafficking through training, education, and leadership initiatives; codes of conduct; supply chain management; and financial analysis. This paper will examine the latest in these strategies and approaches by businesses in the global war against human trafficking, in addition to a discussion of a new initiative engaging the private sector co-led by Dr. Louise Shelley and Christina Bain through the World Economic Forum's Global Agenda Council Network.
\end{abstract}

\section{Keywords}

business and human rights; corporate social responsibility; human trafficking; illicit economy

\section{Issue}

This commentary is part of the special issue "Perspectives on Human Trafficking and Modern Forms of Slavery", edited by Siddharth Kara (Harvard Kennedy School of Government, USA).

(C) 2015 by the authors; licensee Cogitatio (Lisbon, Portugal). This article is licensed under a Creative Commons Attribution 4.0 International License (CC BY).

\section{Introduction}

As thought leaders continue to examine and strategize solutions to human trafficking on a local, national, and global scale, much attention has been paid to the drivers within the illicit economy. At this critical juncture in the anti-trafficking movement, more research, discussion, and inclusion need to be focused on how to address this issue through a business lens. Current and emerging business leaders have a crucial role to play, whether as the head of major corporations and imparting social value or embarking on social enterprises or applying business-thinking to non-governmental organizations. There is an important role also of employees of corporations to use their positions and the resources that are provided by the corporations to serve their communities in ways that advance the anti-trafficking effort. Therefore, anti-trafficking efforts can and do consist of both top down and grassroots efforts.

Human trafficking is a business, and a profitable one with profits estimated in the billions of dollars annually according to the International Labour Organization (International Labour Organization, 2014). This business, in some ways, mirrors the trade within the legitimate economy. Human trafficking intersects in many ways with the legitimate economy through supply chains, transport and logistics, finance and payments as well as facilitators (Aronowitz, Theuermann, \& Tyurykanova, 2010). Corporations, non-governmental organizations, and social enterprises are at the core of 
fighting this egregious human rights abuse. Corporations in many different sectors may be both facilitators of human trafficking and their employees, without proper training or codes of conduct, may fail to act responsibly or proactively in this area.

The problem of human trafficking will be with us in coming decades. Therefore, to provide sustainable action and results, business leaders and business schools training the next generation of business leaders must be engaged and invited to the anti-trafficking movement. This concern with human trafficking must be part of courses on supply chain risk, corporate social responsibility and on entrepreneurship. In order to succeed in today's unpredictable world, leaders must have more than just functional business skills, but also a societal view and appreciation. It must be integrated into less specialized courses as well but into an appreciation that the increasingly global business environment should not result in inattention to the rights of human beings as exemplified by the problem of both labor and sex trafficking (Schlesinger, Kiefer, \& Brown, 2012, p. xviii). ${ }^{1}$

If future business leaders are trained to expand and rethink existing frameworks in solving business and societal challenges, issues like human trafficking can be addressed from within: legitimate business models and solutions combatting illicit business models and practices (Shelley, 2010). Whether leading a major corporation or starting a new non-governmental organization, business students are now trained through an entrepreneurial lens to solve the world's most difficult and pressing global dilemmas.

Current business leaders have an immediate role to play. This is particularly important in sectors where exploitation is most likely to occur such as travel and tourism, construction, manufacturing, retail, seafood processing, and financial services. According to the International Labour Organization, nearly 21 million globally are estimated to be held in forced labor (International Labour Organization, 2012). Of this total global estimate, $68 \%$ are labor exploitation victims within a diversity of sectors while $22 \%$ are sexual exploitation victims (International Labour Organization, 2012).

Through training of leadership and personnel; establishing standards of conduct and performance; supply chain identification; and financial analysis, businesses have the ability to eliminate human trafficking, particularly labor trafficking. There is increasing involvement of the corporate sector in combating human trafficking but this involvement is not well-known. Rather, information on this activity is hidden within corporate responsibility reports of corporations; evaluations of funded programs; or corporate magazines.

\footnotetext{
1 Illustrative of this is the teaching methodologies like Babson College's Entrepreneurial Thought and Action ${ }^{\circledR}$ (ETA) that confirms that entrepreneurs are made and not born, and that they lead at all stages, levels, and types of organizations.
}

Although many believe good works are best done anonymously, this is most probably not the case in human trafficking. Corporate leadership that is visible in the anti-trafficking movement would probably be of much greater value in changing the culture of the business world. As one senior corporate executive who has taken a lead has said, "Many CEOs still do not understand the magnitude of human trafficking and the dire need for a coordinated global business response" (Manpower, n.d.).

With the above in mind, in 2013, the World Economic Forum (WEF) launched the Global Agenda Council Network-Wide Human Trafficking Task Force, a cross-council collaboration formed amongst the then 86 Global Agenda Councils. The Global Agenda Council network was formed in 2008 in order to address the world's most pressing global concerns and now currently contains over 1,500 thought experts (World Economic Forum, 2014). Utilizing the platform of the World Economic Forum, the Task Force was created in order to compile the most promising practices in the business community in anti-trafficking strategies and solutions in the six key sectors of travel and tourism, construction, retail, manufacturing, seafood processing, and financial services. A toolkit publication is presently being formed, constructed of submissions from a variety of corporations and partner organizations, and a future workshop will be held, the World Economic Forum represents an ideal community to highlight the efforts that have been achieved by major corporations in combating human trafficking. By providing an analysis of corporate successes created by corporate leadership and by employees, it is hoped that large corporations and small and mid-sized corporations (which have fewer resources to develop initiatives) will learn and benefit from the lessons learned and successful strategies.

\section{Corporate Anti-Trafficking Efforts: A Sectoral Approach}

In this discussion paper, key sectors will be addressed in the following sections citing their individual current strengths in anti-trafficking strategies and the challenges being encountered.

The greatest strengths in corporate anti-trafficking efforts have been identified in hospitality, technology, and financial services. Much less success has been identified in areas that involve supply chains and labor trafficking such as production of consumer goods, food items, and construction.

Market forces, reputation, and the possibility for affecting change, all appear to be key elements in the readiness and the ability of corporations to engage in human trafficking. There are few corporations, other than Carlson Rezidor, where the head of the corporation has made anti-human trafficking a key policy of the corporation. Rather, the process of engagement with human trafficking appears to result from many different 
forces including: the desire of corporate employees to address this issue, the possibility of sanctions if there is not change, consumer boycotts and protests. The fact that some corporations have been implicated in human trafficking or have been shown to buy from suppliers who have engaged in labor trafficking has made companies that are doing the right thing hesitant to reveal their practices. General research prior to the World Economic Forum initiative has revealed corporations in the construction sector and in consumer products who are making significant efforts to stop these practices but choose not to be identified. They also do not want to share lessons learned. Fears of litigation, corporate reputation, as well as consumer boycotts for past behaviour all figure in their desire to fail to disclose their serious internal efforts to stop human trafficking.

In the case of the travel and tourism industry, antitrafficking strategies and efforts seem to be flourishing. This particular sector has made significant strides mainly due to the following factors: a coalition effort with other companies in the travel and tourism industry; an emphasis on public-private partnerships with government and NGOs; and leadership from within the company, whether from top executives or employee initiatives.

Leadership in the travel and tourism has come from three sources: company heads, personnel, and partnerships with non-governmental organizations (NGOs). Marilyn Carlson Nelson, former Chairman of Carlson, Inc., was on the forefront of not only the travel and tourism industry's engagement in the fight against trafficking, but began a new era of involvement from the business community. Her leadership spurned a whole new sub- movement with the broader anti-trafficking movement (MacMillan, n.d.). In addition, employees at Carlson have also initiated further work, trainings, and education programs within the corporation. Marriott International and Hilton Worldwide have learned from these efforts in launching their training programs and/or have allowed initiatives by corporate employees seeking to leverage company resources to counter human trafficking.

The tourism industry has been involved with NGOs in an effort to more effectively combat human trafficking, particularly child trafficking. In 1998, the NGO End Child Prostitution, Child Pornography, and Trafficking of Children for Sexual Purposes (ECPAT) developed The Code (The Code of Conduct for the Protection of Children from Sexual Exploitation in Travel and Tourism), a series of guidelines and tools for the travel and tourism industry to combat child sex tourism. When a company signs on to The Code, the company commits to 6 steps to protecting children including: establishing company policies that combat sexual exploitation of children; training of employees in the rights of children, prevention, and reporting; contract clauses of zero tolerance with suppliers; provide information to travellers on children's rights, prevention, and how to report; work with other stakeholders; and finally, create annual re- ports on these efforts (The Code, 2012). ECPAT created The Code in partnership with the travel and tourism industry and established this effective collaboration. Within 10 years, 900 companies from 34 countries had signed on as members (The Code, n.d.). A separate non-profit organization formed in 2004 entitled The Code.Org which furthers this work, and the organization's website hosts a public online a public online database for consumers to research travel and tourism companies and their codes of conduct. This dual-pronged strategy makes consumers an active partner in this effort to reduce the risk of child sex trafficking. The involvement of more sectors contributes to success.

New ways of involving the tourism industry in antitrafficking have emerged building on the strength of the initial ECPAT effort. In 2010, the U.S. State Department's Trafficking in Persons office awarded a grant of $\$ 200,000$ for the Youth Career Initiative ( $\mathrm{YCl}$ ) which partners with Marriott and other hotel chains to provide at-risk youth vocational training and skills within the travel and tourism industry (Marriott International, Inc., 2010). This specific grant allowed for the training of victims of sexual exploitation in Mexico, Brazil, and Vietnam, and Marriott played a key role in implementing this grant once it was awarded (Marriott International, Inc., 2011). In Mexico, for example, Fundación Infantia, a local NGO that combats child sexual exploitation, assists in coordinating the $\mathrm{YCl}$ program. $\mathrm{YCl}$ is currently operating in twelve top properties in Mexico and has assisted 340 young trainees nationwide (Youth Career Initiative [YCl], n.d.). Hilton Hotels has also initiated their own programs to train and employ survivors of human trafficking. These are promising examples of emerging public-private partnerships with corporate sector involvement.

The tourism industry has also worked with Sabre, an early signer of The Code, to use technology to address human trafficking (Sabre, n.d.). Sabre is not only using its technology to support the tourism industry as a means of targeting human trafficking but is also providing online anti-trafficking training; scholarships for former victims; and working to promote improved legislation. Therefore, its support of trafficking goes beyond its technical capacity.

Technology also can play a significant role in the fight against trafficking outside of the tourism sector. There are some banking, financial service, technology, and Internet companies that have engaged in fighting human trafficking. The utility of their activities suggests that it is crucial that the anti-trafficking movement more broadly engage the tech industry. Many firms, because they are not immediately involved with human beings, (like the members of the tourism and transport industries) do not understand how their involvement is crucial to combating human trafficking.

The most obvious point of interaction between human trafficking and technology is the Internet. Victims of human trafficking are often recruited, advertised, and 
exploited through the Internet. Child pornography, often marketed through the Internet, is a crime that often uses sexually trafficked children. It has grown enormously because of the anonymity of the Internet. It is in this area where there is a clear intersection between human trafficking and technology that the most action has been taken by technology firms. Therefore, companies such as Microsoft have in-house capacity to track child pornography and have also been active in funding research to help address the linkages between human trafficking and technology (Microsoft, 2012).

The capacity of tech firms to do metadata analysis is extremely important in identifying and tracking human technology. This has been shown in tracking the on-line ads posted through companies such as Craigslist (Latonero, 2011), enabling researchers and law enforcement to understand some of the networks and criminals involved in human technology. But there is also an important role for banks and financial companies to play in using the large scale data to identify possible cases of human trafficking.

Fincen, the agency of the U.S. Treasury, responsible for monitoring money laundering requires the reporting of suspicious financial transactions. Unfortunately, in the case of human trafficking, there is rarely a single interaction that is suspicious. Only in the amalgam and by discovering patterns of financial flows can one identify human trafficking. Therefore, financial firms can only find human trafficking by developing computer programs that mine large amounts of data incorporating insights concerning human trafficking patterns. J.P. Morgan was a pioneer in this effort and these techniques have now been adopted by other corporations in the financial sector. Building on these successes, there is now a public-private partnership between the prosecutors in New York City and the financial services community, the center of the financial industry in New York (Large, 2013). This partnership reveals that important efforts can be based on local initiatives and are not dependent on the efforts of the federal government.

Technology companies outside the financial sector can also provide assistance in important ways. Palantir has provided software and expertise to the Polaris Project to help mine and map the data from the US human trafficking hotline (Palantir, 2014). Polaris partners with many strategic anti-trafficking NGOS in different regions of the world. This is just one example of how a company with software to analyse networks is providing pro-bono support to those seeking to map illicit trade in humans being and other commodities.

Technology firms can also help by developing economic training programs through smartphone technologies and by utilizing technical tools to assist law enforcement and governments. Because many traffickers use advanced technology, often developed and owned by the private sector, it is of paramount importance that the technology community become even more in- volved to ensure that the traffickers are not always one or more steps ahead of law enforcement.

\section{Conclusion}

If more sectors continued on the successful path of the travel and tourism, technology, and financial service industries, there would be a significant shift in antitrafficking measures and strategies. It is critical that more sectors begin to address human trafficking, but in order to do so, a safe space must be created for such discussions. Companies must be comfortable with launching these initiatives, free from fear of litigation, negative consumer response, or future backlash from competition. In addition, the importance of addressing human trafficking must be stressed in different ways. It must be shown how it may affect a company's bottom line or reputation. Those that address these issues may gain clientele for their dedication to human rights, especially the rights of women and children. The downsides of their failure to address this issue can be seen in loss of reputation as well as economic and legal repercussions.

There also needs to be a public shift of conscious: the public must give corporations the chance and allow for this safe space to engage in the anti-trafficking movement. This is not to say that all corporations will step up to the plate, and this is where consumers can actively demand for products, services, and environments to be free of trafficked labor and/or sexual exploitation. Citizens can urge corporate social responsibility to include provisions to address human trafficking and corporate philanthropy to include programs to address gender-based violence and human trafficking. Organizations such as Verité now make it possible for corporations to monitor and improve their supply chains to eliminate child labor and other forms of human trafficking (Verité, n.d.).

The movement against human trafficking and modern day slavery is growing and has engaged many different sectors of society globally. The role that these mobilized citizens can take can have enormous impact on the business community as they use their buying power; their force as investors; and their access to media to advance their goals. Therefore, it is important that the business sector voluntarily become more visibly engaged in this issue before they are pressured. Those companies that are already doing much and are unrecognized for their actions must be encouraged to come forth through public-private partnerships. Without the concerted efforts of different sectors of the business community to work with many diverse communities worldwide, the problem of human trafficking will increase. Traffickers have already discovered this highly profitable sector where they can effectively exploit human vulnerability. In order to truly fight this egregious human rights abuse, it is going to take all actors affected by this issue, especially the business sector. 


\section{Conflict of Interests}

The authors declare no conflict of interests.

\section{References}

Aronowitz, A., Theuermann G., \& Tyurykanova, E. (2010). Analysing the business model of human trafficking to better prevent the crime. Vienna: OSCE Office of the Special Representative and Co-ordinator for Combating Trafficking in Human Beings. Retrieved from: http://www.osce.org/files/documents/c/f/69028.pdf

International Labour Organization. (2012). Global estimate on forced labour. ILO. Retrieved from: http:// www.ilo.org/wcmsp5/groups/public/---ed_norm/---de claration/documents/publication/wcms_182004.pdf

International Labour Organization. (2014). Profits and poverty: The economics of forced labour. Geneva: ILO. Retrieved from: http://www.ilo.org/global/ publications/ilo-bookstore/order-online/books/WC MS_243391/lang--en/index.htm

Large, T. (2013, May 7). Banks can help stop human trafficking, says Manhattan prosecutor. Thomson Reuters Foundation. Retrieved from: http://www. trust.org/item/20130502160826-lbpjr

Latonero, M. (2011). Human trafficking online: The role of social networking sites and online classifieds. Retrieved from: https://technologyandtrafficking.usc. edu/report

Manpower (n.d.). Manpower Inc. website. Retrieved from http://www.manpowergroup.com/wps/wcm/conne $\mathrm{ct} /$ manpowergroup-en/home/newsroom/news-rele ases/manpower+inc.+releases+second+corporate+so cial+responsibility+report\#.VMjtEyw6BIE

MacMillan, J. (n.d.). Leading with a cause: Marilyn Carlson Nelson '61 says businesses have the responsibility to "do the right thing". Smith College Alumnae Relations. Retrieved from: http://alumnae.smith. edu/smithstories/leading-with-a-cause
Marriott International, Inc. (2010). Sustainability report update 2010. Marriott. Retrieved from: http:// www.marriott.com/Multimedia/PDF/CorporateRes ponsibility/Marriott_Sustainability_Report_Update _2010.pdf

Marriott International, Inc. (2011). Marriott International's commitment to human rights. Retrieved from http://www.marriott.com/Multimedia/PDF/ Corporate/HumanRights.pdf

Microsoft. (2012, July 18). Shedding light on the role of technology in child sex trafficking. Retrieved from http://news.microsoft.com/2012/07/18/sheddinglight-on-the-role-of-technology-in-child-sex-trafficking

Palantir. (2014, January 24). How Many Years a Slave? Retrieved from https://www.palantir.com/2014/ 01/how-many-years-a-slave

Sabre. (n.d.). Passport to Freedom. Retrieved from http://www.sabre.com/index.php/about/corporate -responsibility/passport-to-freedom

Schlesinger, L., Kiefer, C. \& Brown, P. (2012). Just start: Take action, embrace uncertainty and create the future. Boston, USA: Harvard Business School Publishing.

Shelley, L. (2010). Human trafficking: A global perspective. New York and Cambridge, USA: Cambridge University Press.

The Code. (n.d.). Code of Conduct for the Protection of Children from Sexual Exploitation in Travel and Tourism. Retrieved from http://www.ecpat.net/ sites/default/files/the_code_brochure.pdf

The Code. (2012). About. Retrieved from http://www. thecode.org/about

Verité. (n.d.). Home. Retrieved from http://www.verite.org

World Economic Forum. (2014). Global Agenda Councils. Retrieved from http://www.weforum.org/ community/global-agenda-councils

Youth Career Initiative (YCI). (n.d.). Mexico: $\mathrm{YCl}$ country information. Retrieved from http://www.youth careerinitiative.org/country/mexico

\section{About the Authors}

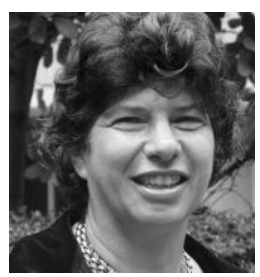

Dr. Louise Shelley

Louise Shelley is the Omer L. and Nancy Hirst Endowed Chair for civic intellectual as well as a University Professor in the School of Policy, Government and International Affairs and the founder and Director of the Terrorism, Transnational Crime and Corruption Center (TraCCC) at George Mason University. Her latest book is Dirty Entanglements: Corruption, Crime and Terrorism (Cambridge University Press, 2014). Her previous book is Human Trafficking: A Global Perspective (Cambridge, 2010).

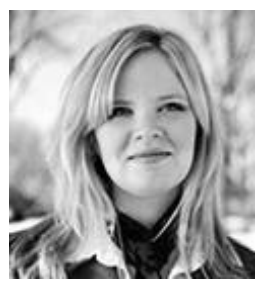

\section{Christina Bain}

Christina Bain is the Director of Babson College's Initiative on Human Trafficking and Modern Slavery where she is focused on the role of business, entrepreneurial solutions, and training the next generation of business leaders in combating human trafficking. Christina is a member of the World Economic Forum's Meta-Council on the Illicit Economy, and the Global Agenda Council on Human Rights. Previously she served as co-Vice Chair of the Global Agenda Council on Illicit Trade and Organized Crime. 